\title{
Expression of the Fragment Gene of Predicted Zymogen Granule Protein (G3MZ19) Homologue in the Bali Cattle (Bos Javanicus) Based on MALDITOF/ TOF.MS Analysis of Bali Cattle Saliva
}

\author{
Sulaiman Ngongu Depamede* \\ *Faculty of Animal Science and Consortium for Large Ruminant Research, Mataram University, Jalan Majapahit-62 Mataram, NTB-83125, Indonesia
}

"Corresponding author: Sulaiman Ngongu Depamede, Faculty of Animal Science and Consortium for Large Ruminant Research, Mataram University, Jalan Majapahit-62 Mataram, NTB-83125, Indonesia, Tel: +62 370 633007; E-mail: depamede@gmail.com; sulaiman_n@unram.ac.id

Rec date: Sep 28, 2015; Acc date: Oct 13, 2015; Pub date: Oct 15, 2015

Copyright: (c) 2015 Depame SN, et al. This is an open-access article distributed under the terms of the Creative Commons Attribution License, which permits unrestricted use, distribution, and reproduction in any medium, provided the original author and source are credited.

\begin{abstract}
Bali cattle (Bos javanicus) are a type of beef cattle native to Indonesia. Their size is relatively smaller (300-600 $\mathrm{kg}$ ) than those of Bos taurus, but Bali cattle have high adaptability to tropical conditions, especially against some diseaeses. Efforts have been done to study the physiology of Bali cattle through their saliva as a non-invasive research material. Predicted Zymogen Granule Protein (G3MZ19) has been reported presence in Bali cattle saliva, however until now has not been characterized. In this paper, the results of our studies on the expression and the phylogenetic study of G3MZ19 fragment gene in Bali cattle are presented. PCR was carried out using the primers developed from Bos Taurus G3MZ19 gene (Ludwig NR database). Our studies revealed that G3MZ19 genes were expressed in the genomic DNA of Bali cattle. Results of dendogram with 1000 bootstrap replications indicate that Bali cattle are located within, but quite distinct from, certain Bos taurus's predicted G3MZ19 genes. In addition to ruminants, in our dendogram analysis, we also incorporated mono gastric (humans and porcines) G3MZ19-related genes. However, evolutionary of Bali cattle G3MZ19 shows only Sus scrofa existed in the dendogram, while humans do not at all. What are the role of this G3MZ19 in Bali cattle, and how accurate its evolution in ruminants still needs to be investigated further?
\end{abstract}

Keywords: Bali cattle; Faliva; Proteomics; Large ruminant; Phylogenetic; MALDITOF/TOF.MS

\section{Introduction}

Bali cattle (Bos javanicus) are native Indonesian cattle, beef type cattle with a relatively small body size, and the adult body weight around $600 \mathrm{~kg}$ in general, although some can be over $600 \mathrm{~kg}$. Even though small in size, Bali cattle are known as the beef cattle that have good adaptation, particularly in the tropics and they are easily handled, hence favored by farmers in the countryside [1]. By 2010 Bali cattle population was around 3.271 million or more than $27 \%$ of the total cattle population in Indonesia [2-4].

Those advantages have increased the curiosity of researchers to elucidate in more detail about the physiology and genetics of Bali cattle. Recently, the use of saliva as a research material, are being given special attention because it is categorized as a non-invasive approach, so it will reduce animal stress during assessment. In the last three years, Depamede and his colleagues have conducted research on proteomics and genomics of Bali cattle saliva. One of their findings was a protein in the saliva of Bali cattle with a molecular weight of about 14 $\mathrm{kDa}$, which has bactericidal activities [5].

Further identification of the $14 \mathrm{kDa}$ protein by matrix-assisted laser desorption ionization time-of-flight tandem mass spectrometry (MALDITOF/TOF.MS) showed that the protein consists of three components. One of these components is the protein sequence with the hit identity of G3MZ19 [4]. Further elaboration showed that G3MZ19 was actually a protein that still has not been identified completely and in the Bos Taurus cattle it is regarded as Predicted Zymogen granule protein 16 homologue B [6].

Zymogen granule protein 16 (ZGP16) was first identified by Cronshagen et al. [7] in the rat body parts, especially in the pancreas, colon, and duodenum using immunocytochemistry techniques. ZPG16 is a member of the mannose-binding protein or mannosebinding lectin (MBL) family, which plays important roles in innate immune system [8,9]. The ability of $14.2 \mathrm{kDa}$ of Bali cattle saliva as bactericidal as reported by Depamede et al. [5] might related with ZPG16 as a component of innanate immune system. Researches on this ZGP16 have been growing steadily, and even reported elsewhere that in humans, ZGP16 had potential as a biomarker for various types of cancers such as hepatocellular carcinoma (HCC), a common cancer worldwide and gastric cancer [10].

Research on ZGP 16 in cattle is still very limited, albeit Zimin et al. [6] have successfully mapped the genes of ZGP16 in Brahman cattle based on human genomic map. In cattle zymogen granule protein is still uncharacterized and designated as Predicted Bos taurus zymogen granule protein 16B (ZG16B). Zymogen granule protein was found also in Bali cattle saliva [4]. This is not surprising since it has been reported that Mus muculus zymogen granule protein gene $(\mathrm{Zg} 16)$ is conserved in human, chimpanzee, rhesus monkey, dog, mouse, rat, and frog [11].

The presence of ZGP in the saliva of Bali cattle (Bos javanicus) which is genetically different from Bos taurus, undoubtedly has gave its own attractiveness for researchers. For that we have done phylogenetic studies on ZGP, which are considered important not only to provide novel information on ZGP evolution in cattle but also to investigate their utility as biomarkers. 
Citation: Depamede SN (2015) Expression of the Fragment Gene of Predicted Zymogen Granule Protein (G3MZ19) Homologue in the Bali Cattle (Bos Javanicus) Based on MALDITOF/TOF.MS Analysis of Bali Cattle Saliva. J Veterinar Sci Technol 6: 260. doi: $10.4172 / 2157-7579.1000260$

Page 2 of 4

\section{Materials and Methods}

\section{Animal samples}

In this study, animals used as source of saliva and blood were nonpregnant and non-lactating Bali cows (Bos javanicus) reared in the "Teaching Farm" of Faculty of Animal Science, Mataram University. The cows were housed in a barn with individual pen, fed with King grass (Pennisetum purpureum) and water was given ad libitum.

Collections of saliva were carried out in the barn from four healthy, non-pregnant and non-lactating cows using disposable plastic pipettes and then processed in the laboratory according to Depamede with some modifications. The saliva was used for proteomic studies using MALDITOF/TOF-MS as reported by Depamede [4]. From those proteomic studies, the accession blast of protein sequence of predicted zymogen granule protein 16 homologue $\mathrm{B}$ found was gil2964735881D.AA15703.1, gil359079571IX, P_002697975.2 [4]. This information then was used for designing of PCR primers.

\section{DNA extraction}

Total genomic DNA was extracted from the pool of four whole blood samples $[12,13]$ of the Bali cattle collected aseptically through the jugular vein. The extractions were carried out using a commercially available kit (NucleoSpin ${ }^{\oplus}$, Macherey-Nagel, Germany) following the manufacturer's instructions. The isolated DNA then subjected a standard PCR analysis.

\section{Detection of G3MZ19 in Bali cattle genomic DNA}

Genomic DNA (20 ng) was subjected to be amplified using KAPA2G Fast Ready MIX PCR Kit (KAPA Biosystem, USA) with the following program: predenaturation for $5 \mathrm{~min}$ at $94^{\circ} \mathrm{C}, 40$ cycles of $40 \mathrm{~s}$ at $94^{\circ} \mathrm{C}, 40 \mathrm{~s}$ at $56^{\circ} \mathrm{C}, 15 \mathrm{~s}$ at $72^{\circ} \mathrm{C}$, followed by a final extension of $5 \mathrm{~min}$ at $72^{\circ} \mathrm{C}$. The primers used for the reactions were ACGTACTATTGGATAATCCCAG (Fwd) and AGTATCCAGGTGAGGTTTGG (Rev), derived from bovine (Bos Taurus, G3MZ19|LOC100295741, Tax_Id=9913, LudwigNR database and UniProt) and were designed using the Primer Quest program of Integrated DNA Technologies (IDT $\left.{ }^{\oplus}, \mathrm{USA}\right)$. The PCR products were subjected to electrophoresis on 7\% gel acrylamide in tris borate EDTA buffer, and samples with a visible band of $306 \mathrm{bp}$ were considered to be positive for G3MZ19 and subjected for DNA sequencing.

\section{DNA Sequencing}

The PCR products were purified using normal commercial kit for PCR clean-up (PureLink ${ }^{\star}$ PCR Purification Kit, Invitrogen/Life Technologies, USA) according to manufacturer's protocols. Purified PCR products were then sequenced directly in both forward and reverse directions using the same primers as for PCR reactions using the ABI PRISM 3730xl Genetic Analyzer develop by Applied Biosystems, USA. While the kit that we used for the sequencing purpose, was BigDye ${ }^{\oplus}$ Terminator v3.1 Cycle Sequencing Kit (Applied Biosystem, Foster City, SA, USA). All of the process was carried out according to manufacturer's procedures.

\section{Phylogenetic analyisis}

Sequence analysis was performed using GENETYX-WIN version 5.1 (Genetyx Corp., Tokyo, Japan). Multiple alignments were generated by CLUSTAL $\mathrm{W}$ [14] and the alignment was confirmed by visual inspection. Phylogenetic trees were constructed using Maximum Likelihood-ancestor model, and the reliability of the phylogenetic trees were determined by analyzing 1000 bootstrap replicates using the MEGA 6 program [15], with the Kimura-2-parameter correction model using online tools in the NCBI nucleotide database, according Hall [15].

\section{Results and Discussion}

This study intends to assess the presence of genes associated with the predicted protein zymogen granule protein found in Bali cattle saliva based on the results of MALDITOF/TOF.MS studies (Figure 1), as reported by Depamede [4]. The number of protein matches at each scoring position is indicated by the height of the red bars. The nonsignificant area is shaded in green. In this histogram, it can be seen a red bar that indicates a protein or peptide that match strongly significant. It is known that this protein in Bos taurus (Hereford) is associated with G3MZ19|LOC100295741, Tax_Id = 9913 (Zimin et al., 2009). From this information, primers for PCR analysis of the fragment of the genes were created. The PCR products were then visualy analyzed using PAGE and revealed that the products were corresponding to the target size of $306 \mathrm{bp}$ (Figure 2). The products were then purified and sequenced.

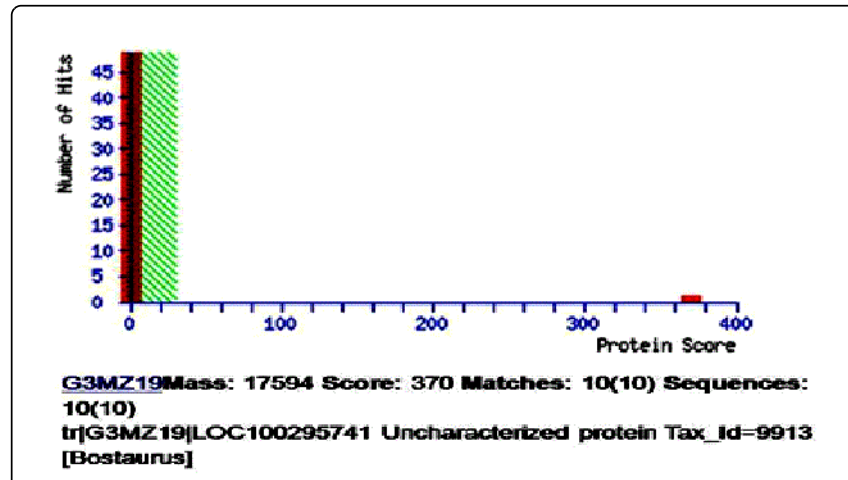

Figure 1: Representation of Mascot search result on G3MZ19 in Bali cattle saliva.

From the results of the sequencing, phylogenetic trees were constructed according to Hall [15]. Starting from aligning the PCR products against the gene sequence associated with zymogen granule proteins of various species through NCBI BLAST. The phylogenetic tree in Figure 3 was constructed according to maximum score of the nucleotide sequences from the NCBI BLAST.

The phylogenetic analyses based on maximum likelihood-ancestor model show that there are at least three groups of different clusters i.e., A, C and $\mathrm{G}$ of zymogen granule protein within animals observed. Of 20 animals collected based on their maximum score, 13 animals are ruminants, 6 are herbivore/pseudo ruminants and only one is a monogastric (Sus scrofa, gi288780680). 
Citation: Depamede SN (2015) Expression of the Fragment Gene of Predicted Zymogen Granule Protein (G3MZ19) Homologue in the Bali Cattle (Bos Javanicus) Based on MALDITOF/TOF.MS Analysis of Bali Cattle Saliva. J Veterinar Sci Technol 6: 260. doi: $10.4172 / 2157-7579.1000260$

Page 3 of 4

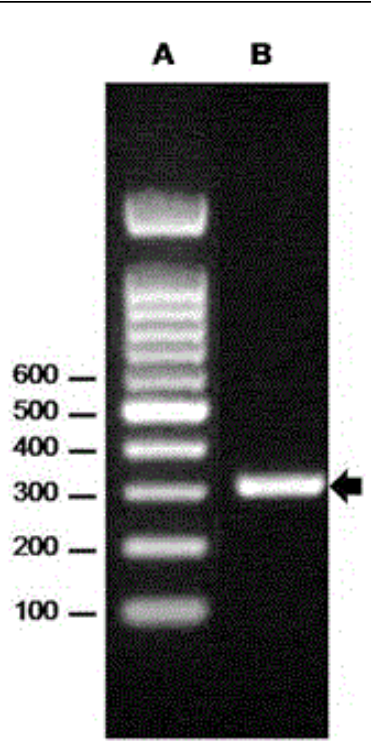

Figure 2: Representation of purified PCR products of Bali cattle G3MZ19 gene of 306 bp (B, arrow); A, DNA size standard.

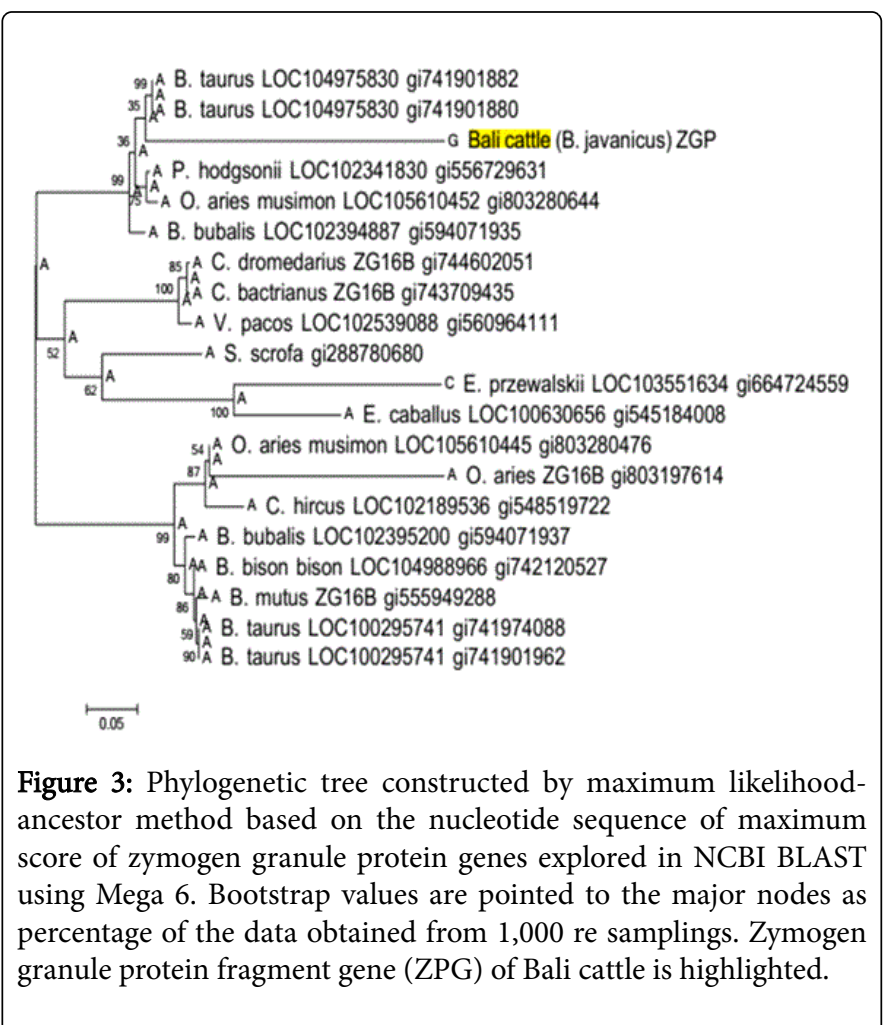

Based on the maximum likelihood-ancestor method, it appears clearly that the entire 20 animals observed in this study come from the same main branch of "A". Interesting phenomenon is seen on Bali cattle. It is noticed clearly that based on the G3MZ19 gene, Bali cattle is clustered under Bos taurus especially for LOC104975830 gi741901882. This can be understood since Bali cattle are indeed included as ruminants. The uniqueness of Bali cattle in this study, according to their G3MZ19 gene, is that Bali cattle fits into notation G, not A.
This phenomenon is as interesting as that shown by E. przewalskii (Equus ferus przewalskii), which got the notation C instead of A like the other family Equidae retrieved in this study.

It is rather difficult actually to explain exactly about the phenomenon of G3MZ19 gene in Bali cattle, since G3MZ19 genes are actually still categorized as predicted zymogen granule protein.

In this study, in addition to ruminants, in the phylogenetic tree analysis, mono gastric (humans and porcines) G3MZ19-related genes were also incorporated. As can be seen in Figures evolutionary of Bali cattle G3MZ19 shows only Sus scrofa existed in the dendogram, while humans do not at all.

Temporary conclusions from this study, therefore is that genes or fragmented genes retrieved from Bos taurus, can be used to assess the presence of predicted zymogen granule protein genes in the Bali cattle genomic DNA. To ensure G3MZ19 gene evolution, further thorough research needs to be done extensively.

\section{Acknowledgements}

This study was supported by the General Directorate of Higher Education, Ministry of Education and Culture, Republic of Indonesia through research competency grant (HIKOM Program), Grant No. 375.D/SP-APHK/UN18.12/PL/2013. Bali cattle were provided by Dr. Dahlanuddin as part of an Australian Centre for International Agricultural Research (ACIAR)-funded collaborative project (LPS 2008-038). Parts of this paper have been presented in The Global Veterinary Summit 2015, Orlando Florida, supported in part by the General Directorate of Higher Education, Ministry of Research, Technology and Higher Education, Republic of Indonesia (No. 1530/ E5.4/BSLN/2015).

\section{References}

1. Martojo H (2012) Indigenous Bali cattle is most suitable for sustainable small farming in Indonesia. Reprod Domest Anim 47 Suppl 1: 10-14.

2. Statistik Peternakan (2010) General Directorate of Livestock. General Directorate of Livestock, Ministry of Agriculture of the Republic of Indonesia, Jakarta, Indonesia.

3. Purwantara B, Noor RR, Andersson G, Rodriguez-Martinez H (2012) Banteng and Bali cattle in Indonesia: status and forecasts. Reprod Domest Anim 47 Suppl 1:2-6.

4. Depamede SN (2013) Proteomic analysis of a $14.2 \mathrm{kDa}$ protein isolated from Bali cattle (Bos sondaicus/javanicus) saliva using 1-D SDS-PAGE gel and MALDITOF-TOF mass spectrometer. Ital J Anim Sci vol12: e59.

5. Depamede SN, Asri N, Julisaniah NI, Suryadi BF, Kisworo D (2012) Isolation and partial purification of lysozyme from saliva of Bali cattle (Bos sondaicus) using an aqueous mixture of polyethylene glycol (PEG) with sodium sulfate. Afr J Biotechnol 11: 1977-1980.

6. Zimin AV, Delcher AL, Florea L, Kelley DR, Schatz MC, et al. (2009) A whole-genome assembly of the domestic cow, Bos taurus. Genome Biol 10: R42.

7. Cronshagen U, Voland P, Kern HF (1994) cDNA cloning and characterization of a novel $16 \mathrm{kDa}$ protein located in zymogen granules of rat pancreas and goblet cells of the gut. Eur J Cell Biol 65: 366-377.

8. Van Asbeck, Hoepelman EC, Scharringa AIM, Herpers J, Verhoef BL, (2008) Mannose binding lectin plays a crucial role in innate immunity against yeast by enhanced complement activation and enhanced uptake of polymorphonuclear cells. BMC Microbiol 8: 229.

9. Lambourne J, Agranoff D, Herbrecht D, Troke PF, Buchbinder A, et al. (2009) Association of mannosebinding lectin deficiency with acute invasive aspergillosis in immunocompromised patients. Clin Infect Dis 49: 1486-1491. 
Citation: Depamede SN (2015) Expression of the Fragment Gene of Predicted Zymogen Granule Protein (G3MZ19) Homologue in the Bali Cattle (Bos Javanicus) Based on MALDITOF/TOF.MS Analysis of Bali Cattle Saliva. J Veterinar Sci Technol 6: 260. doi: $10.4172 / 2157-7579.1000260$

Page 4 of 4

10. Zhou YB, Cao JB, Yang HM, Zhu H, Xu ZG, (2007) hZG16, a novel human secreted protein expressed in liver, was down-regulated in hepatocellular carcinoma. Biochem. Biophys Res Commun 355: 679-686.

11. NCBI. 2014. http://www.ncbi.nlm.nih.gov/gene? $\mathrm{Db}=$ gene\&Cmd=DetailsSearch \& Term $=69036$.

12. Hartmann A, Knoop D, Tiemann C (2010) Isolation and purifiation of genomic DNA and viral RNA from clinical samples with Thermo Scientific King Fisher Flex.Thermo Fisher Scientific Inc.

13. Page K, Hava N, Ward B, Brown J, Guttery DS, et al. (2011) Detection of HER2 amplification in circulating free DNA in patients with breast cancer. Br J Cancer 104: 1342-1348.
14. Thompson JD1, Higgins DG, Gibson TJ (1994) Improved sensitivity of profile searches through the use of sequence weights and gap excision. Comput Appl Biosci 10: 19-29.

15. Tamura K, Stecher G, Peterson D, Filipski A, Kumar S (2013) MEGA6: Molecular Evolutionary Genetics Analysis version 6.0. Mol Biol Evol 30: 2725-2729.

16. Hall BG1 (2013) Building phylogenetic trees from molecular data with MEGA. Mol Biol Evol 30: 1229-1235. 